African Journal of Educational Studies in Mathematics and Sciences Vol. 15, No. 2., 2019

\title{
Insights of teachers and students on mathematics teaching and learning in selected Rwandan secondary schools
}

\author{
F. Ukobizaba ${ }^{1}$, K. Ndihokubwayo ${ }^{2}$, A. Mukuka $^{3} \&$ J. Uwamahoro ${ }^{4}$
}

\begin{abstract}
Effective teaching and learning of mathematics are vital not only for examination or assessment purposes but also for empowering learners to live in a modern age of science, mathematics, and engineering and enable them to role-play to the social and economic development of the developing countries and the whole world as well. This study reveals insights of teachers and students regarding mathematics teaching and learning in Rwanda. The study was a survey designed involving 217 ordinary level secondary school students and 25 secondary school teachers who teach Mathematics, from 5 schools in Karongi District, Western Province, in Rwanda. The results analysis was confined to three components namely; preferred mathematics teaching methods, motivation to teach and learn mathematics, and the usability of mathematics in daily life. Descriptive statistics and all the statistical tables/graphs were generated using SPSS and MS Excel. As results, peer learning and group work and expository were found to be the most applied teaching methods in the selected schools. This study has underlined that not only parents but also siblings have an impact on their young brothers/sisters' education. In terms of its utilitarian value, respondents revealed that mathematics increases critical thinking, problem-solving skills, and creativity of students. Teachers need to be more knowledgeable in the subject matter, through lesson preparations and linking mathematical concepts to real-world experiences.
\end{abstract}

Keywords: $\quad$ teachers and students' insights; mathematics teaching and learning methods; motivation to learn mathematics, the usability of mathematics; mathematics in daily life

\section{Introduction}

Mathematics has been portrayed as a complex subject by most of the learners especially in SubSaharan Africa (SSA) where standards have been extremely low. Bethell (2016) observed that it would take several years for SSA countries to reach the levels comparable to their counterparts of the high-flying income economies of East Asia if the problem of low achievement in mathematics is not addressed accordingly and urgently. One of the efforts aimed at realising such expectations in Rwanda (Rwanda Education Board, 2015) includes that of reviewing the curriculum to align it with national aspirations and to ensure that the knowledge, skills, attitudes, and values acquired by learners are consistent with the requirements of the $21^{\text {st }}$ century skills. It is also believed that equipping learners with necessary skills could lead to the development of a knowledge-based economy that can propel individual citizens to compete in the global market.

\section{Literature review and Theoretical framework}

Many years ago, a lot of research projects on mathematics classroom learning environments have been carried out not only in Rwanda but across the world. Apart from provision good home

1,2,3\&4Ukobizaba Fidele, Ndihokubwayo Kizito, Mukuka Angel and Uwamahoro Jean' African Centre of Excellence for Innovative Teaching and Learning Mathematics and Science (ACEITLMS), University of Rwanda - College of Education (UR-CE), Rukara, Kayonza, Rwanda. PO. BOX: 55 Rwamagana. 1Email: ukobifidele@gmail.com, +250783749466; ndihokubwayokizito@gmail.com, +250788970243

Open Access article distributed under the terms of the Creative Commons Attributions License [CC BY-NC-ND 4.0] http://creativecommons.org/licenses/by-nc-nd/4.0. DOI: https://dx.doi.org/10.4314/ajesms.v15i2.8 
Insights of teachers and students on mathematics teaching and learning in selected Rwandan secondary schools

\section{F. Ukobizaba, K. Ndihokubwayo, A. Mukuka \& J. Uwamahoro}

environment (Carmichael \& MacDonald, 2016), various factors responsible for students to lose motivation in mathematics such as lack of teacher motivation, low students' literacy abilities in understanding the mathematical problems and less parental involvement have been highlighted (Shahrill, Abdullah, \& Yusof, 2015). In the study investigating the teachers' beliefs on motivating factor to students learning approach used to address their learning motivation (Matteson, Swarthout, \& Zientek, 2011), the results indicated that teachers believe that motivation is vital towards learning, though it is difficult for teachers to identify motivational strategies associated with pedagogy and curriculum, while some of them emphasized utilizing tangible rewards. Since mathematics learning is challenging and may include nervousness; therefore, Kaphesi (2014) argues that perseverance as the on-going effort will be needed to bring prize; and positive or negative perception of mathematics learning is related to the active or passive role of the learner $\mathrm{him} /$ herself. For instance, learner-centred teaching approaches have been recognised as one of the most effective approaches to implement in mathematics classrooms in order to tackle and reduce significantly the problem of underachievement (Nsengimana, Habimana, \& Mutarutinya, 2017). Though Mathematics is perceived to be complex and difficult (Miranda-Tirado \& Marisa, 2015), learning mathematics enables us to possess knowledge to solve everyday problems, make daily needed calculations and operations as well as to think logically, teaching mathematics involves transmitting knowledge and reasoning ability, and showing how to share it and solve problems. This negative attitude towards the subject has led to a loss of interest in mathematics by most learners in most African countries of which Rwanda is part (International Mathematics Union, 2014).

While students perceive that only bright students are favoured during mathematics lesson, mathematics teachers believe that all learners may involve depending on the teaching method used. For instance, class discussion helps students to provide their views about the problem while authentic problems help them to appreciate the usefulness of mathematics in real life (Aloquina \& Marpa, 2016). In their investigations, Mutodi and Ngirande (2014) found that the perceptions shared by the students in South Africa about mathematics performance are due to one's selfconfidence, family background, teacher teaching/learning materials, interest in mathematics, traditions, and beliefs. Difficulties and weaknesses in mathematics are the main causes of such perceptions. As far as parents are concerned, Mutodi and Ngirande (2014) confirmed that students who accredited their success to the interest, self-confidence, as well as family background, have a chance to come up with higher achievements than those who point their academic success to chance and natural talent. Indeed, Haque \& Farhana (2017) and Makeo (2013) have investigated and found out that parents 'perception of mathematics has an influence on their children's perception, and hence influence their performance. Moreover, there is no contradiction between mathematics that takes place in the classroom compared to that one that takes place outside the classroom (Schoenfeld, 1989). A study conducted in South African schools (Tsanwani, Harding, Engelbrecht, \& Maree, 2014), it was expressed by educators and learners that their commitment and motivation, learners' attitudes, self-concepts, career prospects, their perceptions of peers and teachers as well as teachers' perceptions of learners are factors inducing underprivileged learners' judgments to continue and achieve in mathematics in spite of their problematic settings.

A sociological theory of knowledge towards human development known as social constructivism theory of Lev Vygotsky will guide the present study. This theory is socially positioned so that knowledge is created through collaboration with other people (McKinley, 2015). It declares that individuals work together to create pieces of art as learning is not "no man is an island" and cannot be separable from its social context. Similarly, sociocultural learning as one of Vygotsky's theories which stress on the role of social and cultural interactions in the learning 
process has no stages, like constructivism of Jean Piaget rather, it emphasises that knowledge is co-built and that people learn from each other. This is named a social-constructivist theory because according to Vygotsky (1962), the learner must be involved in the learning process. A central aspect of this theory is the zone of proximal development (ZPD). This is a range of tasks that are too difficult to master on its own but can be grasped with the help or direction of more qualified

adults or peers. Scaffolding is another part of this theory, which consists of providing the learner with an accurate quantity of support at the right interval of time. If the learner can do an activity with a little help, he/she is nearer to understanding it. The present theory has a relationship with vigorous adolescent development because if learners work in pairs, they interact with their fellow mates and can grasp various conceptual ideas from each other. Therefore, this theory displays that students learn from each other; they can help each other and co-build knowledge together. Not only the social-constructivism theory, but the attitude theory of Icek Ajzen will also be applied to this study in order to grasp the teaching and learning motivation of teachers and learners respectively. Since attitude can have cognitive, affective, or behavioural components (Lolliot et al., 2015) we generally form beliefs about some objects by connecting it with certain characteristics like with another object, attributes, or events. As an example of a certain teaching approach (attitude object), we may come to believe that this approach is efficient and actively engaging (attributes) students (Ajzen, 1993).

\section{Research problem}

Though Cooke (2018) suggests three lenses that adults - educators, family, and caregivers - can use to help them identify mathematical ideas, there are many related people such as siblings that can help learners to effectively study and perform mathematics and we could not get literature related. Despite calls on moving away from expository teaching to learner-centred approaches and also from knowledge-based to competence-based learning, not much is known about teachers' and students' perceptions on the teaching and learning of mathematics in Rwanda. Since if one wants to be successful in life, he/she, therefore, needs sources of mathematics (Kalhotra, 2013), it is in this regard, this paper attempts to reveal the insights of teachers and students concerning teaching and learning of mathematics while being with teachers or not. Understanding teachers' and students' experiences on the way mathematics is currently taught in Rwanda is necessary for the sense that it gives the overall picture of the challenges faced. Insight about students perception with respect to their mathematical experience can ascertain benefit in evolving effective pedagogy for better mathematical accomplishment (Mutodi \& Ngirande, 2014). The implication of these perceptions may alert pedagogical thoughts in enlightening the mathematics teaching and learning motivations in Rwandan teachers and students.

In light of the above, this paper endeavours to provide answers to the following research questions.

(i) What are the most preferred mathematics teaching and learning methods in selected Rwandan secondary schools?

(ii) Which factors motivate teachers and students in teaching and learning mathematics in selected Rwandan secondary schools?

(iii) How are the teachers' and students aware of real-life applications of mathematics?

Providing answers to the above research questions will provide insights into how the teaching of mathematics in Rwanda and other similar contexts could be made more relevant to societal needs. 
Insights of teachers and students on mathematics teaching and learning in selected Rwandan secondary schools

\section{F. Ukobizaba, K. Ndihokubwayo, A. Mukuka \& J. Uwamahoro}

\section{Methods used}

Before the commencement of data collection, school leaders were consulted as to when their respective schools would be visited by the researchers to gather the intended information. When the researchers arrived at school, they handled a letter to the authority requesting the data collection approval within a selected school. Cluster sampling technique was used to collect data (Fraenkel, Wallen, \& Hyun, 2012). In fact, five schools were selected from Karongi district, in the Western province of Rwanda. The study accommodated a total of 217 students (113 male and 104 female) with an average age of 15 years old. The study also accommodated 25 secondary school teachers with 1 up to 33 years of teaching experience. Students were selected from ordinary level secondary schools; senior one up to senior three (grade 7 up to grade 9) where 40 students were from senior one, 82 from senior two, while 95 were from senior three. Students were found in their classroom setting while learning, with an authorisation from the head teacher (HT) or director of studies (DOS), the teacher could embrace the researchers and then allow them to explain all the concerns of the research as well as how the questionnaire is going to be answered. Students had to accept voluntarily to participate in the research before being given questionnaires. Students were free to ask questions before and during the filling of the questionnaire about the research or about the item for more clarifications. The same approach applied also to the teachers who were given questionnaires after reading the purpose of the research and then agree voluntarily to participate in the research.

In order to provide answers to the three research questions, the present study employed a descriptive survey design. The researchers themselves designed the questionnaires based on research questions. This means those questionnaire items were centred on three components: (i) preferred mathematics teaching and learning methods, (ii) motivation to teach and learn mathematics, and (iii) usability of mathematics in daily life. The coverage of items are also constructed based on the social-cultural and attitude frameworks guiding this study in a way that students learning methods are explained by social-constructivism theory of Lev Vygotsky while motivation towards teaching will be explained by attitude theory of Icek Ajzen. Questionnaires were administered in English to both students and teachers of mathematics. Apart from personal information items, the questionnaire for students contained about 22 item questions while a questionnaire for teachers contained 11 items. Items within the questionnaire were ranked in a 4type Likert-scale ranging from 1 (Strongly agree) to 4 (strongly disagree) as well as from 1 (never) to 4 (often). The validity of items was checked to assure that the content and the format of the questionnaire are appropriate, meaningful, and correct towards the research questions and social constructivism theory that will guide this study. The internal consistence of the questionnaire was also checked and calculated using the Kuder-Richardson approach. Therefore, the reliability estimate for answers on the students' questionnaire was .93 while the one on the teachers was .71 . For data analysis and presentation, frequency tables were used. Since most items reported in this paper were intended to collect ordinal data, the number of responses for each item was displayed in form of frequency percentages to highlight the proportion of respondents who agreed in comparison to those who disagreed to a particular statement.

\section{Results presentation}

Findings are presented according to research questions. In addressing each research question, students' responses are presented first followed by teachers' responses. 
Research question 1: What are the most preferred mathematics teaching and learning methods in selected Rwandan secondary schools?

\section{Students' responses}

Students were asked to indicate their most preferred mode of learning. Table 1 gives a summary of the students' responses.

Table 1: Learning methods preferred by students

\begin{tabular}{lccccc}
\hline \multirow{2}{*}{$\begin{array}{l}\text { Indicate your level of agreement to each of the following } \\
\text { statements. }\end{array}$} & $\begin{array}{c}\text { Total } \\
\text { responses }(n)\end{array}$ & $\begin{array}{c}\text { Strongly } \\
\text { agree }\end{array}$ & Agree & Disagree $\begin{array}{c}\text { Strongly } \\
\text { disagree }\end{array}$ \\
\hline To learn math by working together with my mates outside class & 204 & 25.0 & 39.7 & 19.6 & 15.7 \\
To learn math by studying in groups & 209 & 62.2 & 29.2 & 6.2 & 2.4 \\
To learn math by students teaching each other in pair & 209 & 61.2 & 26.3 & 6.7 & 5.7 \\
\hline
\end{tabular}

Of the total responses for each of the items in Table 1, the most preferred mode of learning by students was "learning in groups" which accounted for $91.4 \%$ of students who either agreed or strongly agreed compared to $8.6 \%$ who disagreed or strongly disagreed. Similarly, $87.6 \%$ of respondents agreed that they preferred learning mathematics in pairs by having one student teaching a fellow student while $12.4 \%$ disagreed to the statement. On learning mathematics together with classmates outside the classroom, $64.7 \%$ agreed to the statement while $35.3 \%$ disagreed to the statement. Therefore, it can be seen that the students preferred leaning method confirms the social constructivism theory that gives the opportunity for learners to study and construct knowledge together. This is elucidating well that if our students are developing a culture of sharing knowledge, this will continuously develop the learning attitude and increase mathematics performance.

After revealing the preferred methods, students were also asked to rate activities done during the learning process in mathematics classrooms. Table 2 gives a summary of the students' responses.

Table 2: Rate of learning activities preferred by students

\begin{tabular}{|c|c|c|c|c|c|}
\hline \multirow{2}{*}{$\begin{array}{l}\text { How often do you do the following } \\
\text { activities in the mathematics lesson? }\end{array}$} & \multirow{2}{*}{$\begin{array}{c}\text { Total } \\
\text { Responses (n) }\end{array}$} & \multicolumn{4}{|c|}{ Frequency percentages $(\%)$} \\
\hline & & Often & Sometimes & Seldom & Never \\
\hline I take a summary of the lesson notes & 209 & 78.9 & 15.8 & 5.3 & 0.0 \\
\hline I do homework & 208 & 70.2 & 25.5 & 3.4 & 1.0 \\
\hline I do exercises & 212 & 71.2 & 23.1 & 4.7 & 0.9 \\
\hline I read books related to math & 206 & 30.1 & 41.3 & 13.1 & 15.5 \\
\hline
\end{tabular}

From Table 2, it is evident that the majority of students took the summary of lesson notes (78.9\%) more often compared to those who only took lesson notes sometimes $(15.8 \%)$ and seldom $(5.3 \%)$. Out of the 208 students who responded to the item regarding how often they did homework, the majority (70.2\%) indicated that they did homework more often compared to $28.8 \%$ who said they did homework sometimes or seldom and $1 \%$ who never did homework. Regarding doing class exercises Table 2 shows that the majority $(71.2 \%)$ were doing exercises often compared to $27.8 \%$ who did exercises sometimes or seldom and $1 \%$ who never did any exercise. Of the 206 responses, only $30.1 \%$ indicated that they read mathematics books often while $54.4 \%$ read mathematics books sometimes or seldom and $15.5 \%$ never read mathematics books. The impression one gets 
Insights of teachers and students on mathematics teaching and learning in selected Rwandan secondary schools

\section{F. Ukobizaba, K. Ndihokubwayo, A. Mukuka \& J. Uwamahoro}

from the results displayed in Table 2 is that the culture of reading mathematics books was not common among students. On the other hand, most of the students (more than $70 \%$ ) revealed that they took lesson notes, did homework and class exercises quite often. Actually, the primary source of knowledge is the Textbook. Therefore, teachers have a responsibility to motivate their learners to visit the library frequently in order to build and aliment their mind. The fact that they work together with their peers; they would likely share the read information during classroom presentation after being advised to exploit this kind of resources.

\section{Teachers' responses}

In an attempt to address the first research question fully, teachers were also asked to indicate by agreeing or disagreeing on the teaching method they found easier to use in their mathematics classrooms. Table 3 summarises the responses from teachers.

Table 3: Teaching method preferred by teachers

\begin{tabular}{|c|c|c|c|c|c|}
\hline \multirow[b]{2}{*}{$\begin{array}{l}\text { Indicate by agreeing or disagreeing with each of } \\
\text { the statements. }\end{array}$} & \multirow{2}{*}{$\begin{array}{c}\text { Total } \\
\text { Responses } \\
(n)\end{array}$} & \multicolumn{4}{|c|}{ Frequency percentages $(\%)$} \\
\hline & & $\begin{array}{l}\text { Strongly } \\
\text { agree }\end{array}$ & Agree & Disagree & $\begin{array}{l}\text { Strongly } \\
\text { disagree }\end{array}$ \\
\hline I use the expository method of teaching & 22 & 9.2 & 41.0 & 36.2 & 13.6 \\
\hline I put my students into groups to discuss the concept & 25 & 68.0 & 32.0 & 0.0 & 0.0 \\
\hline I allow students to teach one another in a pairs & 23 & 26.4 & 69.3 & 4.3 & 0.0 \\
\hline
\end{tabular}

Out of the 22 responses on whether teachers use expository teaching methods, $50.2 \%$ agreed and the other $49.8 \%$ disagreed. On the other hand, all the $25 \%$ of teachers who responded to the item on putting students in groups to discuss the concept agreed to the statement. Additionally, the majority $(95.7 \%)$ of the teachers agreed that they allow their students to teach one another in pairs compared to $4.3 \%$ who disagreed. Both students and teachers seemed to be of the view that teaching of mathematics should be done by grouping students and allowing them to discuss so that more knowledgeable students can teach others. In all, learner-centred teaching methods were the most preferred ones by both teachers and students. Similarly, the scaffolding model of Vygotsky theory asks teachers to set pillars that students will build on learning. The attitude theory also provides a room for the teacher to motivate learners to learn through various methods as long as they grasp the intended knowledge and skills to achieve the learning objectives set by the curriculum and instructional objectives set by the teacher.

Research question 2: Which factors motivate teachers and students in teaching and learning mathematics in selected Rwandan secondary schools?

\section{Students' responses}

There could be many other factors that motivated students to like mathematics. However, the present study was restricted to the teacher, parent, and sibling-related factors. Students were asked to indicate the level of agreement to the statements displayed in Table 4. 
Table 4: Students' reasons for liking mathematics

\begin{tabular}{|c|c|c|c|c|c|}
\hline \multirow[b]{2}{*}{ What made you to enjoy learning Mathematics? } & \multirow{2}{*}{$\begin{array}{c}\text { Total } \\
\text { responses (n) }\end{array}$} & \multicolumn{4}{|c|}{ Frequency percentage $(\%)$} \\
\hline & & $\begin{array}{c}\text { Strongly } \\
\text { agree }\end{array}$ & Agree & Disagree & $\begin{array}{l}\text { Strongly } \\
\text { disagree }\end{array}$ \\
\hline I got high marks in math tests and exams & 162 & 44.4 & 42.0 & 8.6 & 4.9 \\
\hline A caring teacher to students & 161 & 67.1 & 19.3 & 6.2 & 7.5 \\
\hline A teacher telling lots of stories and link them to math & 168 & 54.2 & 27.4 & 8.9 & 9.5 \\
\hline A teacher using plays and games in teaching activities & 162 & 42.0 & 24.7 & 14.2 & 19.1 \\
\hline Teacher used group work & 165 & 63.6 & 13.9 & 10.9 & 11.5 \\
\hline Teacher gave us a lot of exercise & 171 & 62.6 & 21.1 & 7.6 & 8.8 \\
\hline
\end{tabular}

Results indicate that $86.4 \%$ of the students agreed or strongly agree that they were motivated whenever they got good marks during tests and examinations compared to $13.6 \%$ who disagreed with the statement. Similarly, $86.3 \%$ of the students agreed that they were motivated to do mathematics because their teachers were so caring while $13.7 \%$ disagreed with the statement. Regarding a teacher telling stories and linking them to mathematics, $78.6 \%$ of the students agreed or strongly agreed to the statement while $21.4 \%$ disagreed. A teacher using plays and games in teaching activities was also cited by $66.7 \%$ of the responses as a motivating factor for their enjoyment in learning mathematics. The overall impression one gets from the results displayed in Table 4 is that majority of the students (more than 66\%) either agreed or strongly agreed that each of the above-stated factors motivated them or made them enjoy learning mathematics. It was also interesting in a way that students like teachers who give them a lot of exercises $(83.7 \%$ strongly agree or agree with the statement) and who put them in the working group (77.5\% strongly agree or agree with the statement). Therefore, this shows how students are motivated to learn mathematics without fear as before.

Apart from teacher-related factors, it was also noted that parents play a role in their children's education. Table 5 below gives a summary of responses from students.

Table 5: Role of parents in their children' learning

\begin{tabular}{lccccc}
\hline \multirow{2}{*}{$\begin{array}{l}\text { Indicate how your parents help in your learning of } \\
\text { Mathematics. }\end{array}$} & \multirow{2}{*}{$\begin{array}{c}\text { Total } \\
\text { responses }(n)\end{array}$} & $\begin{array}{c}\text { Strongly } \\
\text { agree }\end{array}$ & Agree & Disagree $\begin{array}{c}\text { Strongly } \\
\text { disagree }\end{array}$ \\
\hline My parents help me to do homework of math & 210 & 24.8 & 26.7 & 14.3 & 34.3 \\
My parents make a follow up about my performance in math & 208 & 34.6 & 24.0 & 13.9 & 27.4 \\
My parents visit me at school and talk to my math teacher & 189 & 10.1 & 16.4 & 19.6 & 54.0 \\
\hline
\end{tabular}

Slightly above half (51.4\%) of the students agreed or strongly agreed that their parents helped them to do homework while $48.6 \%$ disagreed to the statement. Similarly, $58.7 \%$ of the students indicated that their parents made follow-ups on their performance in mathematics while $41.3 \%$ disagreed to the statement. Though, Vygotsky's social-cultural theory impacts on students' learning, however, the majority of students $(73.5 \%)$ indicated that their parents did not visit them at school and have a talk with their mathematics teachers compared to $26.5 \%$ who indicated that they were visited by parents. The attitude of a learner who is full assisted is different from one who is not. For instance, if parents support their children whether they are busy or not, the children will develop the motivation to increase their performance and like mathematics. As mathematics 
Insights of teachers and students on mathematics teaching and learning in selected Rwandan secondary schools

\section{F. Ukobizaba, K. Ndihokubwayo, A. Mukuka \& J. Uwamahoro}

is claimed to be difficult, therefore, parents have to close this difficulty and perception gap and motivate children.

Not only parents, elder brothers/sisters also have a responsibility to their young brothers/sisters' learning. Table 6 below gives a summary of responses from students.

Table 6: Role of elder brothers/sisters in their siblings' learning

\begin{tabular}{lccccc}
\hline & \multirow{2}{*}{$\begin{array}{c}\text { Total } \\
\text { What do your elder brothers/sisters assist you }\end{array}$} & \multicolumn{4}{c}{ Frequency percentages (\%) } \\
\cline { 3 - 6 } $\begin{array}{l}\text { in learning Mathematics? } \\
(n)\end{array}$ & 152 & 21.0 & 34.3 & 11.8 & 32.9 \\
\hline Helping me doing math homework & 155 & 34.8 & 29.0 & 5.2 & 31.0 \\
Encouraging me to do math homework & 158 & 31.6 & 25.4 & 11.4 & 31.6 \\
Showing me the importance of math & 153 & 22.2 & 21.6 & 6.5 & 49.7 \\
Giving me some numbers to perform in math & & & & Seldom & Never \\
\hline
\end{tabular}

About $55.3 \%$ and $63.8 \%$ of the students agreed or strongly agreed that their elder brothers/sisters helped and encourage them respectively to do homework while $44.7 \%$ and $36.2 \%$ disagreed to the statement. Similarly, $57.0 \%$ of the students indicated that their elder brothers/sisters showed them the importance of mathematics while $43.0 \%$ disagreed to the statement. However, few students $(43.8 \%)$ indicated that their elder brothers/sisters gave them some numbers to perform in mathematics compared to $56.2 \%$ who indicated that they were not given works related to mathematics to perform. It has been so long claiming parents to help and assist their children, however, it can be seen that not only teachers and parents, but also siblings have a big role and impact on helping their little brothers and sisters. This may take the source from the motivation of elder brothers and sisters to show off their capacity and retain the proud of their families. However, this support has some limitation as you may find in a family; children are in one grade preventing the elder to help the youngest. Even though they are in different grade but if they are at the same age, they will disrespect each other.

\section{Teachers' responses}

Teachers were also asked to indicate the level of agreement to what motivated them to teach mathematics. Table 7 displays their responses.

Table 7: Teachers' motivation to teach mathematics

\begin{tabular}{|c|c|c|c|c|c|}
\hline \multirow[b]{2}{*}{ What motivates you in teaching mathematics? } & \multirow{2}{*}{$\begin{array}{c}\text { Total } \\
\text { Responses } \\
(n)\end{array}$} & \multicolumn{4}{|c|}{ Frequency percentages $(\%)$} \\
\hline & & $\begin{array}{c}\text { Strongly } \\
\text { agree }\end{array}$ & Agree & Disagree & $\begin{array}{l}\text { Strongly } \\
\text { disagree }\end{array}$ \\
\hline Seeing students scoring highly & 25 & 40.0 & 60.0 & 0.0 & 0.0 \\
\hline Seeing students following carefully & 25 & 52.0 & 48.0 & 0.0 & 0.0 \\
\hline Seeing students asking questions & 24 & 62.5 & 37.5 & 0.0 & 0.0 \\
\hline Seeing students doing exercises and homework & 25 & 64.0 & 32.0 & 4.0 & 0.0 \\
\hline Seeing students taking notes & 24 & 37.5 & 25.0 & 29.2 & 8.3 \\
\hline
\end{tabular}

Even though taking notes was not interested to majority (more than 62.5\%) of teachers, the overall impression one gets from the results displayed in Table 7 above is that most $(99 \%)$ of teachers who responded to each of the items strongly agreed or agreed that they were motivated to teach mathematics whenever they saw their students (i) scoring highly during tests and exams, (ii) 
following lesson carefully, (iii) participating in the lessons by asking questions, and (iv) doing exercises and home works. About all teachers, $60.0 \%$ and $40.0 \%$ of the teachers agreed or strongly agreed that they like seeing students scoring high while $48.0 \%$ and $52.0 \%$ agreed or strongly agreed that they like seeing students following carefully during teaching and learning activities. Similarly, $37.5 \%$ and $62.5 \%$ of teachers agreed and strongly agreed respectively seeing students asking questions. However, $4.0 \%$ of teachers disagree that they like seeing their students doing exercises and homework while $29.2 \%$ and $8.3 \%$ of teachers disagree and strongly disagree that they like seeing the students taking notes. This is the product of learning altogether. For instance, the zone of proximal development in Vygotsky's theory explains this clearly. Thus, due to the difficulty of mathematics, when students learn through group work, they discuss each other, therefore develop conceptual understanding and achieve at a high score. The attitude theory requests learners to motivate teachers. When for example students score high, following carefully and asking questions, teachers get motivated to proceed, improve, and plan for the next lesson. Teachers need motivation from students who show the ability and love of what they are taught as well as from parents and siblings to support their learners when they get home. Though some teachers showed a little interest that students should do exercises, homework and taking notes, however, teachers should advise and encourage students to develop writing skills and have memo taking habitude.

Research question 3: What are teachers' and students' level of awareness about real-life applications of mathematics?

\section{Students' responses}

In order to address the above research question, both students and teachers were asked to indicate the level of agreement to each of the items regarding real-life applications of mathematics. Table 8 displays the students' views.

Table 8: Students' views on real-life applications of mathematics

\begin{tabular}{|c|c|c|c|c|c|}
\hline \multirow[b]{2}{*}{ What do you think Mathematics will help you in life? } & \multirow[b]{2}{*}{$\begin{array}{c}\text { Total } \\
\text { responses (n) }\end{array}$} & \multicolumn{4}{|c|}{ Frequency percentage $(\%)$} \\
\hline & & $\begin{array}{l}\text { Strongly } \\
\text { agree }\end{array}$ & Agree & Disagree & $\begin{array}{l}\text { Strongly } \\
\text { disagree }\end{array}$ \\
\hline Enhancing critical thinking skills and problem solving & 207 & 63.8 & 24.2 & 6.3 & 3.9 \\
\hline $\begin{array}{l}\text { Being creative, systematic and self-confident in using } \\
\text { mathematical language }\end{array}$ & 207 & 60.9 & 29.5 & 8.7 & 1.0 \\
\hline $\begin{array}{l}\text { To succeed in a rapid technologic growth and socio- } \\
\text { economic development }\end{array}$ & 210 & 70.0 & 21.9 & 5.2 & 2.9 \\
\hline
\end{tabular}

Results displayed in Table 8 reflect that most of the students $(87.9 \%)$ agreed that mathematics helps in enhancing critical thinking and problem-solving skills while $12.1 \%$ disagreed to the statement. Similarly, $90.3 \%$ of the students agreed or strongly agreed that being knowledgeable in mathematics brings about creativity, being systematic and self-confident in solving real-world problems with related mathematical ideas. The majority of students $(91.9 \%)$ also indicated that mathematical knowledge was necessary for someone to succeed in a rapidly changing world of technology and socio-economic development while $8.1 \%$ disagreed with the statement. Overall, results displayed in Table 8 above reflects that most of the students (more than 87\%) who responded to each item were aware of the stated real-life applications of mathematics. The fact that students know the usability of mathematics, the motivation increased due to this attitude. So, learning should be accompanied by the application of what students learn from the class. Though it is difficult to fully apply what we learn at school apart from engineering schools, however, if 
Insights of teachers and students on mathematics teaching and learning in selected Rwandan secondary schools

\section{F. Ukobizaba, K. Ndihokubwayo, A. Mukuka \& J. Uwamahoro}

we know at least where what we learnt is applied, this can help us and motivate us to master and further learning.

\section{Teachers' responses}

Teachers also needed to indicate the level of agreement on the real-life applications of mathematics. Table 9 below gives a summary of teachers' responses.

Table 9: Importance of mathematics towards students' life

\begin{tabular}{|c|c|c|c|c|c|}
\hline \multirow[b]{2}{*}{$\begin{array}{l}\text { What do you think mathematics will help your } \\
\text { students in life? }\end{array}$} & \multirow{2}{*}{$\begin{array}{c}\text { Total } \\
\text { Responses } \\
(n)\end{array}$} & \multicolumn{4}{|c|}{ Frequency percentages $(\%)$} \\
\hline & & $\begin{array}{l}\text { Strongly } \\
\text { agree }\end{array}$ & Agree & Disagree & $\begin{array}{l}\text { Strongly } \\
\text { disagree }\end{array}$ \\
\hline $\begin{array}{l}\text { Enhancing critical thinking skills and problem- } \\
\text { solving }\end{array}$ & 25 & 68.0 & 32.0 & 0.0 & 0.0 \\
\hline $\begin{array}{l}\text { Being creative, systematic and self-confident in } \\
\text { using mathematical language }\end{array}$ & 24 & 45.8 & 50.0 & 4.2 & 0.0 \\
\hline $\begin{array}{l}\text { To succeed in rapid technological growth and } \\
\text { socio-economic development }\end{array}$ & 25 & 52.0 & 48.0 & 0.0 & 0.0 \\
\hline
\end{tabular}

Results displayed in Table 9 above also reflect that almost all the teachers involved in the study (more than 99\%) were aware of those real-life applications of mathematics. About $32.0 \%$ and $68.0 \%$ of the teachers agreed or strongly agreed that enhancing critical thinking skills and problem-solving will help their students in life while none of them disagreed to the statement. Similarly, $48.0 \%$ and $52.2 \%$ of the teachers indicated that their students will succeed in rapid technological growth and socio-economic development through studying mathematics. Though $50.0 \%$ and $45.8 \%$ of the teachers agreed or strongly agreed that mathematics will help their students in life if they are creative, systematic and self-confident in using mathematical language, $4.2 \%$ disagreed to the statement. The zone of proximal development (ZPD) will, without doubt, achieve its intention when learners study mathematics in knowing its usability. This will make to learn it with all their potential, where difficult, they interact with their fellow mates so that the built of the economy-based nation gets successful as a wish of Rwanda. The attitude of the teacher to know and elaborate on the importance of learning mathematics would help and motivate students in learning and like mathematics. This motivation will also play a role for both teachers and students. For instance, students get motivated when studying mathematics purposively while it is easy for teachers to teach students who are motivated to learn.

\section{Discussion of the findings}

Most of the students perceive mathematics as a difficult subject owing to a number of reasons some of which includes aversive teaching methods, lack of family basis assistance, lack of motivation, and awareness of usability of mathematics in daily life. These were some of the compelling grounds that triggered us to conduct this study.

Firstly, from the results presented, both students and teachers agreed that the teaching of mathematics should be done by grouping students and allowing them to discuss so that more knowledgeable students can help their peers. Several pieces of research contend that group works permit learners to generalise and transmit their knowledge into classroom and provides a solid foundation for oral communication of ideas (Reznitskaya, Anderson, \& Kuo, 2007), play a critical role in improving learners' capability to check their thoughts, summarize others' thoughts and deepen their understanding of what they learn (Corden, 2001). Discussions in small and large groups also provides students with the opportunity to self-regulate, to self-determination and to 
persist in their tasks (Matsumura, Slater, \& Crosson, 2008), while increasing communication and sharing their opinions rising their aptitude to support their critical thinking, develop their mental skills, and assert their views in a persuasive and respectful way (Reznitskaya et al., 2007). In addition, the discussion raises learner motivation, collaborative skills, and skillfulness to solve problems as it is suggested by Rwandan new competence-based curriculum (Rwanda Education Board, 2015) and as it upkeeps and builds on theories of social constructivism. Although both teachers and students preferred learner-centred teaching methods, effective implementation of these methods of teaching is still problematic. In fact, about $50 \%$ of the teachers indicated that they preferred using expository methods of teaching in their classrooms. This is why Nsengimana et al. (2017) recommended that teachers needed to be oriented on how they can implement learnercentred teaching methods effectively. This calls for more research on how pre-service, as well as in-service teachers, can be oriented and encouraged to use learner-centred teaching methods especially in contexts like that of Sub-Saharan Africa, specifically Rwanda where such methods are not implemented effectively. These findings also support the notion that educators need to keep up to date with new teaching strategies and content knowledge. Moreover, according to Alsardary and Blumberg (2009), the learners studied other cross-disciplinary skills like presentation skills, how to provide feedback to their classmates, learn from and trust them. Teachers should strongly focus on active learning. For instance, Campbell et al. (2001) argued that when teachers engage students and create a supportive environment, the learning is centred to student and knowledge translation to skills while when old-style expository teaching approaches were used exclusively, students will only focus on diffusion and reproduction of knowledge.

Secondly, results indicate that students were motivated to learn mathematics by caring teachers and through group work and peer learning. Though it was found that parents use dialogue while guiding their children and depend on examples as basic learning assistance style (Eloff \& Miller, 2016), in the resent study students indicated that parents do not care about their education. On top of that sibling was a motivating factor. For instance, elder brothers/sisters have been found to help and encourage their fellow young siblings in mathematics learning. These findings point to the need to embrace classroom instruction that builds on students' emerging capabilities in understanding and reasoning in both tangible and intangible terms (Protheroe, 2007). The authors suggest that the awareness of mathematics in daily life is connected to learner's mathematics usefulness. In the study conducted by Kaphesi (2014), it was highlighted that hard work, endurance and determination are needed for students' mathematics success. Therefore, we may argue that when students know their role, they likely learn mathematics in a smooth way. It is very crucial to notice that there are so many different reasons why students fail some subjects including Mathematics. Parents and society as a whole are responsible for these reasons (Kalhotra, 2013). Thus, students also need to be cared for and encouraged to enjoy mathematics by both teachers and parents and more importantly by their siblings, in their home ground. Sanchal and Kuiti (2013) also point out that learning in a generous nonthreatening environment increases students' level of engagement and enjoyment during mathematics lessons. These findings appear to suggest that teachers need to exhibit a high level of interest and show students how much they like mathematics so that they influence their students' insights about the subject. Carvalho (2015) affirms that teachers who are confident with mathematics have a tendency to impart that confidence upon their students. Therefore, teachers need to demonstrate to the students that mathematics is a key element that will sharpen their thinking capacity in solving real-world problems as at the social constructivism point of view, the sense of belonging to a community and teamwork in the classroom increases by offering more opportunities for learners to exchange together. 
Insights of teachers and students on mathematics teaching and learning in selected Rwandan secondary schools

\section{F. Ukobizaba, K. Ndihokubwayo, A. Mukuka \& J. Uwamahoro}

Thirdly, both teachers and students agreed that mathematics increases critical thinking and problem-solving skills. Students and teachers were also aware that mathematical knowledge enables learners to be innovative and creative. They further agreed that mathematics enables them to cope with the ever-changing and increasing complexity of science and technology in the modern world. Based on these findings, there is an urgent need for mathematics education to shift towards distinguishing where mathematics is appropriate, interpreting practical results into mathematical problems and assessing the outcomes rather than solving the mathematical problems without a link to real-world experiences (Gravemeijer, Stephan, Julie, Lin, \& Ohtani, 2017). Despite its importance and calls for teachers to teach mathematics in a real-world context, Rwandan school teachers appear not to abide by such calls. A study conducted by Uwizeyimana et al., 2018) in Rwanda, revealed that most of the teachers $(80 \%)$ claimed to use everyday life examples during their teaching, while only less than half of the students $(42.6 \%)$ indicated that they can link the concepts they learned to real-world experiences. Another study by Ndihokubwayo and Habiyaremye (2018) revealed that Rwandan teachers claimed that some contents were too heavy for learners' level and that some class exercises have no link to real-world experiences. Such revelations are a clear testimony that students should have an opportunity to see a broad expanse of mathematics applications in order for them to find relations between their benefits and ambitions and their mathematics coursework. Qualitative research by Miranda-Tirado \& Marisa (2015) has highlighted that Mathematics is essential in daily life to develop ones' careers. It is important in a way that it is in everything that surrounds us and makes us able to solve daily life problems as well as a subject that develops thinking skills. Moreover, the influence of motivating students developing positive beliefs towards mathematics learning goals should be sensitised from pre-service to professional development programs (Matteson et al., 2011). Therefore, in order to inspire and motivate students to be independent learners, innovators, and critical thinkers, teachers should demonstrate a learner-centred approach; promote inclusivity and professional career guidance, create smooth interaction among students within and outside the classroom. They should offer a clear lesson delivering philosophy with a deep and logical approach in order to expand their teaching practice while demonstrating a thorough and methodical focus on caring student learning.

\section{Conclusion and implications}

Based on the findings of this study, there is an immediate need to sensitise both parents and siblings on a family setting, to adopt a numeracy culture, where children and their parents will be working hands in hands in order to solve day to day mathematical problems. Furthermore, elder brothers/sisters can highly help their fellow siblings in doing mathematics exercises and homework after school and at home, thereafter developing their self-efficacy and real-world contexts. Sibling in addition to parental contribution has been identified as one of the motivating factors for their children's enjoyment of mathematics as parental dedication and support for their children's dedication and their obligation to school's parent-teacher interactions/meetings can help in raising the learners' performance not only in mathematics but other subjects as well. It is also important to sensitise serving teachers and trainee teachers on the effective implementation of learner-centred methods of teaching. Both teachers and students who participated in this study are aware of the various real-life applications of mathematics including, but not limited to increase in learners' critical thinking and problem-solving skills, innovation and creativity, and learners' ability to cope with the modern world of science and technology. In this regard, teachers need to step up their efforts towards identifying where mathematics is pertinent and translating applied to mathematical problems as they interact with learners in the classroom. Findings of this study also suggest that caring teachers enable students to enjoy learning mathematics. Lastly, there is a call 
for the government to prepare and administer mathematics test and call students on a national wide level to compete in order to motivate students to like and learn mathematics effectively. Since this research has been conducted in one part of the country intending to generalise the findings, the researchers based on the findings recommend that further studies should be conducted on the wider range of the country for more generalisation and comparison and early numeracy practice within siblings boost mathematics insight from family setting to a community as a whole.

\section{References}

Ajzen, I. (1993). Attitude theory and the attitude-behavior relation. In In Krebs, D. and Schmidt, $P$. (eds), New directions in attitude measurement (pp. 41-57).

Aloquina, M. L. B., \& Marpa, E. P. (2016). Mathematics Teachers' and Students 'Perceptions on the Implementation of the Dynamic Learning Program. International Journal of Scientific and Research Publications, 6(8), 429-436.

Alsardary, S., \& Blumberg, P. (2009). Interactive, Learner-Centered Methods of Teaching Mathematics. PRIMUS, 19(4), 401-416. https://doi.org/10.1080/10511970701678596

Bethell, G. (2016). Mathematics Education in Sub-Saharan Africa: Status, Challenges, and Opportunities. Africa. Retrieved from https://elibrary.worldbank.org/doi/abs/10.1596/25289

Campbell, J., Smith, D., Boulton-Lewis, G., Brownlee, J., Burnett, P. C., Carrington, S., \& Purdie, N. (2001). Students' Perceptions of Teaching and Learning: The influence of students' approaches to learning and teachers' approaches to teaching. Teachers and Teaching, 7(2), 173-187. https://doi.org/10.1080/13540600120054964

Carmichael, C., \& MacDonald, A. (2016). Parental influences on primary school children's mathematics achievement: insights from the Longitudinal Study of Australian Children. Education 3-13, 44(2), 197-211. https://doi.org/10.1080/03004279.2014.939684

Carvalho, D. (2015). Senior-Level Math Teachers' Perceptions on Student and Teacher Math Anxiety in the Classroom. Zeitschrift fur Romanische Philologie. University of Toronto.

Cooke, A. (2018). An argument to engage really young children in mathematics Young Children Engaging with Mathematics. In 41st annual conference of the Mathematics Education Research Group of Australasia (pp. 242-249). Auckland: MERGA. Retrieved from https://files.eric.ed.gov/fulltext/ED592419.pdf

Corden, R. . (2001). Group discussion and the importance of a shared perspective: Learning from collaborative research. Qualitative Research, 1(3), 347-367.

Eloff, J. G. M., \& Miller, L. H. (2016). The role of parents' learning facilitation mode in supporting informal learning in mathematics. Early Child Development and Care, 176(3-4), 313-328. https://doi.org/10.1080/03004430500092217

Fraenkel, J. R., Wallen, N. E., \& Hyun, H. H. (2012). How to Design and Evaluate Research in Education (8th ed.). New York: McGraw Hill.

Gravemeijer, K., Stephan, M., Julie, C., Lin, F., \& Ohtani, M. (2017). What Mathematics Education May Prepare Students for the Society of the Future? Int Jo of Sci and Math Educ, 105-123. https://doi.org/10.1007/s10763-017-9814-6

Haque, M., \& Farhana, K. (2017). Behavior Relationship between Parent's Attitude towards Math and Children's Math Anxiety. Journal of Child \& Adolescent Behavior, 5(4), 10-12. 
Insights of teachers and students on mathematics teaching and learning in selected Rwandan secondary schools

F. Ukobizaba, K. Ndihokubwayo, A. Mukuka \& J. Uwamahoro https://doi.org/10.4172/2375-4494.1000354

International Mathematics Union. (2014). Mathematics in Africa: Challenges and Opportunities. Seoul, Korea.

Kalhotra, S. K. (2013). A Study of Causes of Failure in Mathematics at High School Stage. Academic Research International, 4(5), 588-599.

Kaphesi, E. (2014). Third-year University Mathematics Education Students' Metaphorical Understanding of Mathematics Teaching and Learning. African Journal of Research in Mathematics, Science and Technology Education, 18(3), 276-286. https://doi.org/10.1080/10288457.2014.962729

Lolliot, S., Fell, B., Schmid, K., Wolfer, R., Swart, H., Voci, A., ... Hewstone, M. (2015). Measures of Intergroup Contact. In Measures of Personality and Social Psychological Constructs (pp. 652-683). Elsevier. Retrieved from http://www.hermannswart.com/wpcontent/uploads/2014/09/2014_Lolliot-et-al-Measures-of-intergroup-contact.pdf

Makeo, E. M. (2013). Student and Teacher Perceptions of Factors Influencing Students ' Performance in KCSE Mathematics in Tana River County, Kenya. Kenyatta University. Retrieved from https://ir-library.ku.ac.ke/bitstream/handle/123456789/9049/Makeo\%2C Evans Mwajumwa.pdf? sequence=1

Matsumura, L. C., Slater, S. C., \& Crosson, A. (2008). Classroom climate, rigorous instruction and curriculum, and students' interactions in urban middle schools. The Elementary School Journal, 108(4), 294-312.

Matteson, S. M., Swarthout, M. B., \& Zientek, L. R. (2011). Student Motivation: Perspectives from Mathematics Teachers. Action in Teacher Education, 33(3), 283-297. https://doi.org/10.1080/01626620.2011.592123

McKinley, J. (2015). Critical Argument and Writer Identity: Social Constructivism as a Theoretical Framework for EFL Academic Writing. Critical Inquiry in Language Studies, 12(3), 184-207. https://doi.org/10.1080/15427587.2015.1060558

Miranda-Tirado, G., \& Marisa, M.-S. (2015). Mexican high school students' social representations of mathematics, its teaching and learning. International Journal of Mathematical Education in Science and Technology, 46(5), 700-720. https://doi.org/10.1080/0020739X.2014.997319

Mutodi, P., \& Ngirande, H. (2014). The Influence of Students 'Perceptions on Mathematics Performance. A Case of a Selected High School in South Africa. Mediterranean Journal of Social Sciences, 5(3), 431-445. https://doi.org/10.5901/mjss.2014.v5n3p431

Ndihokubwayo, K., \& Habiyaremye, H. T. (2018). Why Did Rwanda Shift from Knowledge to Competence Based Curriculum? Syllabuses and Textbooks Point of View. African Research Review, 12(3), 56-65.

Nsengimana, T., Habimana, S., \& Mutarutinya, V. (2017). Mathematics and science Teachers' Understanding and Practices of Learner - Centred Education in Nine Secondary Schools from Three Districts in Rwanda. Rwandan Journal of Education, 4(1), 55-68.

Protheroe, N. (2007). What does good math teaching look like? Principal. Research Report. Retrieved from https://www.naesp.org/sites/default/files/resources/2/Principal/2007/SOp51.pdf

Reznitskaya, A., Anderson, R. C., \& Kuo, L. J. (2007). Teaching and Learning Argumentation. 
African Journal of Educational Studies in Mathematics and Sciences Vol. 15, No. 2., 2019

Elementary School Journal, 107, 449-472.

Rwanda Education Board. (2015). Competency Based Curriculum-Summary of Curriculum Framework Pre-Primary to Upper Secondary. Rwanda Education Board. Retrieved from $\mathrm{http} / / /$ reb.rw/fileadmin/competence_based_curriculum/syllabi/curriculum_framework_final _printed.compressed.pdf

Sanchal, A., \& Sashi, S. (2017). Students' attitudes towards learning mathematics: impact of teaching in a sporting context. Teachers and Curriculum, 17(1), 89-99.

Schoenfeld, A. H. (1989). Explorations of Students' Mathematical Beliefs and Behavior. Journal for Research in Mathematics Education, 20(4), 338-355.

Shahrill, M., Abdullah, N. A., \& Yusof, J. M. S. (2015). Factors Affecting Students' Performance in Mathematics: Case Studies in Three Primary Schools. In The 7th ICMI-East Asia Conference on Mathematics Education In Pursuit of Quality Mathematics Education for All (pp. 1-15). Cebu City, Philippines: $\quad$ EARCOME 7. https://doi.org/10.13140/RG.2.1.1398.1609

Tsanwani, A., Harding, A., Engelbrecht, J., \& Maree, K. (2014). Perceptions of Teachers and Learners about Factors that Facilitate Learners' Performance in Mathematics in South Africa. African Journal of Research in Mathematics, Science and Technology Education, 18(1), 40 51. https://doi.org/10.1080/10288457.2014.884262

Uwizeyimana, D., Yadav, L. L., Musengimana, T., \& Uwamahoro, J. (2018). The impact of teaching approaches on effective physics learning: an investigation conducted in five Secondary Schools in Rusizi District, Rwanda. Rwandan Journal of Education, 4(2), 4-14.

Vygotsky, L. S. (1962). Thought and language. Cambridge, MA: MIT Press. 